\title{
Sciendo
}

RURAL SUSTAINABILITY RESEARCH 45 (340), 2021

ISSN - 2256-0939

(c) Latvia University of Life Sciences and Technologies, all rights reserved http://www.Ilu.Iv/en/

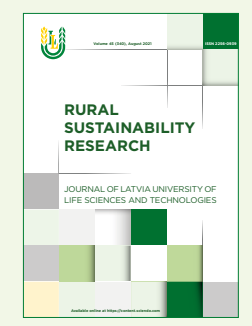

Received: 12 November 2020

Revised: 22 February 2021

Accepted: 4 March 2021

\section{Impact of Crop Rotation and Soil Tillage on the Severity of Winter Wheat Leaf Blotches}

\author{
*Biruta Bankina, Gunita Bimšteine, Irina Arhipova, Jānis Kaṇeps, Madara Darguža \\ Latvia University of Life Sciences and Technologies, 2 Liela street, Jelgava, Latvia
}

\begin{abstract}
Reduced tillage is considered as one of the main tools to save biological diversity; however, it increases pressure of diseases, including wheat leaf blotches. The aim of present study was to clarify the impact of reduced soil tillage on the development of winter wheat leaf blotches in different schemes of crop rotation. The impact of different growing technologies on the severity of winter wheat disease was evaluated in a two-factorial experiment: A - soil tillage system, and B - different combinations of wheat pre-pre-crop and pre-crop (wheat, oilseed rape, barley and faba beans). Diseases were assessed every 10 days approximately and total impact of diseases was evaluated by calculating AUDPC (Area under Diseases Progress Curve). Tan spot, caused by Pyrenophora tritici-repentis was dominated disease over the long period, regardless of meteorological conditions. Development of Septoria leaf blotch was not influenced by neither crop rotation nor soil tillage. The level of tan spot was essentially higher after wheat, regardless of the pre-pre-crop. Reduced soil tillage promoted severity of tan spot. Ploughing mitigated effect of previous crops and differences in tan spot level were insignificant. Despite many positive effects of conservation tillage, increasing of fungicide treatment could be necessary, in conditions, when the tan spot is most devastating and widespread wheat disease.
\end{abstract}

Key words: Pyrenophora tritici-repentis, Zymoseptoria tritici, pre-crop, pre-pre-crop, reduced tillage.

\section{Introduction}

Soil loss and necessity to save and improve fertility of soil is a global problem for the long-term sustainability of agriculture systems. Conservation soil tillage is considering management tool for reducing soil erosion and maintenance of soil microbiological diversity. Previous research proved significant increasing of soil organic carbon in reduced soil tillage plots in comparison with ploughing (Conyers et al., 2019; Fernandez et al., 2019).

This method also allows us to save time and resources, at the same time it did not decrease the yield of wheat over a long-term period (Cárcer et al., 2019). Several findings proved that reduction of soil tillage increased the yield and quality of wheat (Biberdzic et al., 2020; Pagnani et al., 2019).

However, several researches showed disadvantages of the implementation of this method. One of the most important problems is augmentation of weediness in fields with lower intensity of soil treatment (Kadziene et al., 2020). Spreading of different harmful cereal diseases is promoted by reduced soil tillage, including ear scab, caused by Fusarium spp. (Matušinsky et al., 2016). Significantly lower level of mycotoxins (DON) was detected in ploughed fields. Combination of reduced soil tillage and short crop rotation or continuous wheat is the most conductive factor for the development of wheat diseases (Bankina et al., 2018; Vega et al., 2019).

Winter wheat leaf diseases is a considerable risk factor of wheat production; therefore, it is necessary to understand importance of agronomic practice on the development of this disease. It is found that leaf blotches are the dominant leaf diseases across Europe (Willocquet et al., 2020). Tan spot, caused by Pyrenophora tritici-repentis and Septoria leaf blotch caused by Zymoseptoria tritici are the most important wheat leaf diseases in many regions of wheat cultivation, including Uruguay, Canada, Baltic region etc. (Bankina et al., 2014; Fernandez et al., 2016a;

\footnotetext{
* Corresponding Author's email:

Biruta.Bankina@1lu.lv
} 
Mazzilli et al., 2016). Our previous investigations showed that reduced soil tillage and continuous wheat sowings significantly increase development of tan spot, but did not reveal the impact of pre-crop (Bankina et al., 2018).

The aim of present study is to clarify the impact of reduced soil tillage on the development of winter wheat leaf blotches in different schemes of crop rotation.

\section{Materials and Methods}

This study is a continuation of the previous research in a field experiment established at the Study and Research Farm "Peterlauki" of the Latvia University of Life Sciences and Technologies $\left(56^{\circ} 30.658^{\circ} \mathrm{C} \mathrm{N}\right.$ and $23^{\circ} 41.580^{\circ} \mathrm{C} \mathrm{E}$ ) in the autumn of 2008 (Bankina et al., 2015, 2018). Soil type at the site was Cambic Calcisol (Bathyruptic, Episiltic, Protostagnic), soil texture was clay.

The present research included results of the years 2017-2020. This period of time was chosen because a full crop rotation after including faba beans was implemented.

The impact of different growing technologies on the severity of winter wheat diseases was evaluated in a two-factorial experiment: A - soil tillage system (A1 traditional soil tillage with ploughing at the depth of 22-24 cm (TT); A2 - reduced soil tillage with disc harrowing up to the depth of $10 \mathrm{~cm}(\mathrm{RT}))$; and $\mathrm{B}-$ different combinations of wheat pre-pre-crop and pre-crop (B1 - continuous wheat (W-W); B2 - wheat, oilseed rape, (W-OR); B3 - oilseed rape, wheat (OR-W); B4 - barley, faba beans (B-FB). The field trial was arranged in a two-factorial split-plot design in two blocks. Each plot in every block was split in half, thus forming four replications.

The late winter wheat cultivar 'Zentos' in 2017, and later on 'Skagen' was used in this period. Cultivars were changed, because 'Zentos' lost topicality among producers. Both cultivars are late, moderately resistant against leaf blotches and has good winterhardiness.

Assessment of disease was carried out approximately every 10 days, from tillering until milk ripeness. Detailed methods of evaluation were described in previous publication (Bankina et al., 2018).

The total disease impact during the vegetation period was estimated by calculating the area under the disease progress curves (AUDPC).

Foliar commercial fungicide epoxiconazole $(62.5$ $\left.\mathrm{g} \mathrm{L}^{-1}\right)+$ pyraclostrobin $\left(85.0 \mathrm{~g} \mathrm{~L}^{-1}\right)$, dose $1 \mathrm{~L} \mathrm{ha}^{-1}$, was sprayed across all wheat plots at the heading stage (according to $\mathrm{BBCH}$ ) every year.

Meteorological conditions differed among the years of investigations (Table 1).

The effects of the year, soil tillage method and

Meteorological conditions during the period of investigations

Table 1

\begin{tabular}{|c|c|c|c|c|}
\hline Year & $\begin{array}{c}\text { Growth } \\
\text { Stages }\end{array}$ & $\begin{array}{c}\text { Number of Rainy } \\
\text { Days }\end{array}$ & $\begin{array}{c}\text { Average Temperature, } \\
{ }^{\circ} \mathbf{C}\end{array}$ & $\begin{array}{c}\text { Amount of Precipitation, } \\
\mathbf{~ m m}\end{array}$ \\
\hline \multirow{4}{*}{2017} & $32-55$ & 12 & 34 & 12.4 \\
\cline { 2 - 5 } & $55-75$ & 24 & 106 & 16.3 \\
\cline { 2 - 5 } & $32-75$ & 36 & 140 & 14.6 \\
\hline \multirow{3}{*}{2018} & $32-55$ & 2 & 6 & 17.2 \\
\cline { 2 - 5 } & $55-75$ & 2 & 2 & 15.2 \\
\cline { 2 - 5 } & $32-75$ & 4 & 8 & 16.8 \\
\hline \multirow{3}{*}{2019} & $32-55$ & 17 & 21 & 12.8 \\
\cline { 2 - 5 } & $55-75$ & 4 & 4 & 20.7 \\
\cline { 2 - 5 } & $32-75$ & 21 & 25 & 15.1 \\
\cline { 2 - 5 } & $32-55$ & 19 & 88 & 10.1 \\
\hline 2020 & $55-75$ & 4 & 26 & 19.8 \\
\cline { 2 - 5 } & $32-75$ & 23 & 113 & 12.4 \\
\hline
\end{tabular}


schemes of crop rotation (pre-pre-crop and pre-crop) on the total level of both diseases were evaluated by using one-way or two-way ANOVA with interaction effects $(p<0.05)$. The post hoc multiple comparison least significant difference (LSD) test was used to determine which groups were significantly different. The main effect of years compared the levels of years (2017-2020) after averaging the levels of soil tillage method and schemes of crop rotations. The main effect of soil tillage method (ploughed and without ploughing) was evaluated after averaging the levels of years and schemes of crop rotations. The main effect of scheme of crop rotation (pre-pre-crop and pre-crop) compared the levels $\mathrm{W}-\mathrm{W}, \mathrm{W}-\mathrm{OR}, \mathrm{OR}-\mathrm{W}, \mathrm{B}-\mathrm{FB}$ after averaging the levels of years and soil tillage method. The soil tillage method by crop rotation interaction evaluated the interaction of the soil tillage system and crop rotation after averaging the years.

\section{Results}

Tan spot was the dominant leaf disease during the whole period of observation, but severity of disease fluctuated depending on the year $(\mathrm{p}<0.001$ for both diseases). Septoria leaf blotch were observed every year, but the level of this disease was significantly lower if compared to tan spot. Both diseases developed similarly only in 2020 (Figure 1).

Soil tillage method significantly influenced severity of both wheat leaf blotches. Ploughing significantly decreased development of tan spot $(p=0.015)$ and increased development of Septoria leaf blotch $(\mathrm{p}=0.017)$ (Figure 2).

Development of tan spot was significantly influenced $(\mathrm{p}=0.005)$ by schemes of crop rotation. The level of tan spot was significantly higher after wheat, regardless of pre-pre-crop - using oilseed rape as pre-pre-crop did not decrease the severity of tan spot

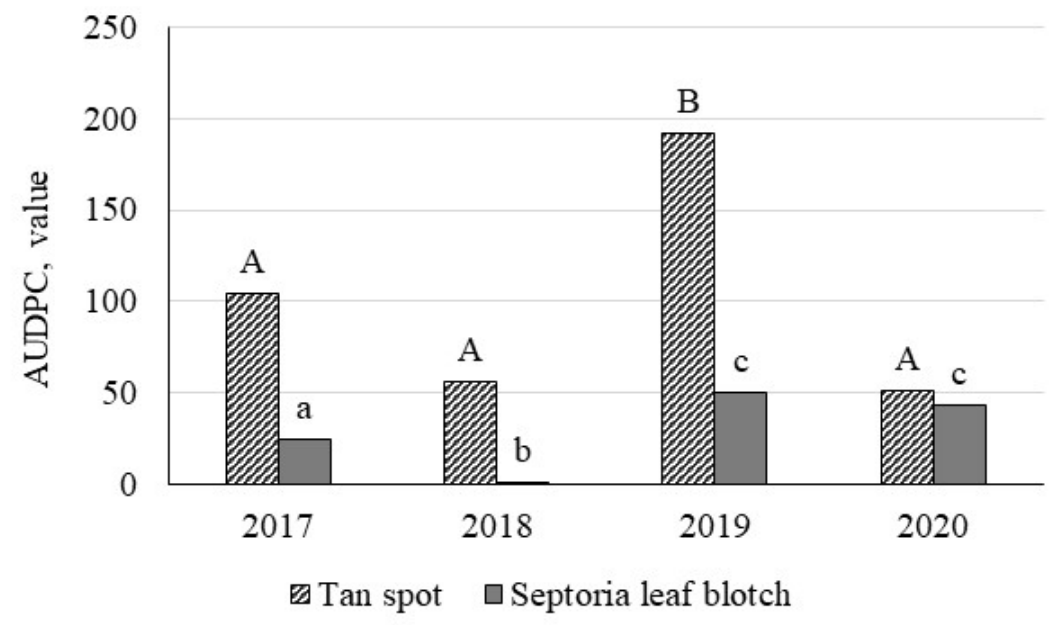

Figure 1. Development of wheat leaf blotches depending on a year (significantly different means are labelled with different letters: A, B - significant difference for AUDPC of tan spot; a, b, c - for Septoria leaf blotch).

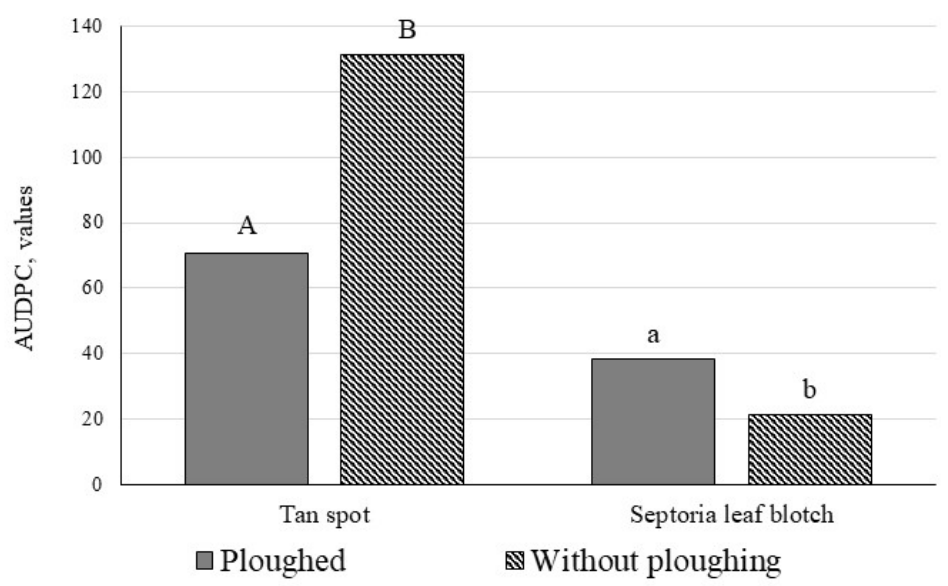

Figure 2. Development of winter wheat leaf blotches depending on soil tillage methods (significantly different means are labelled with different letters: A, B - significant difference for AUDPC of tan spot; $a, b$ - for Septoria leaf blotch). 


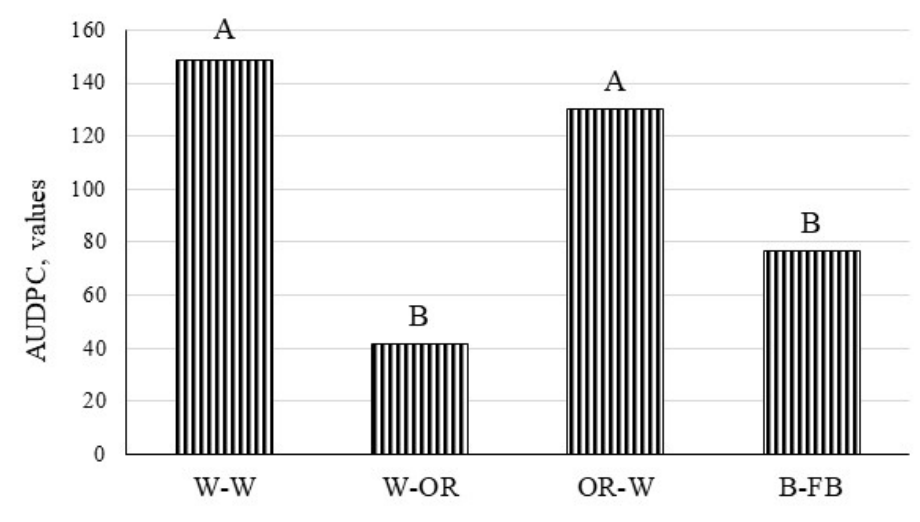

Figure 3. Development of tan spot depending on scheme of crop rotation (pre-pre-crop and pre-crop): W - wheat; OR - oilseed rape; B - barley; FB - faba bean (significantly different means are labelled with different letters).

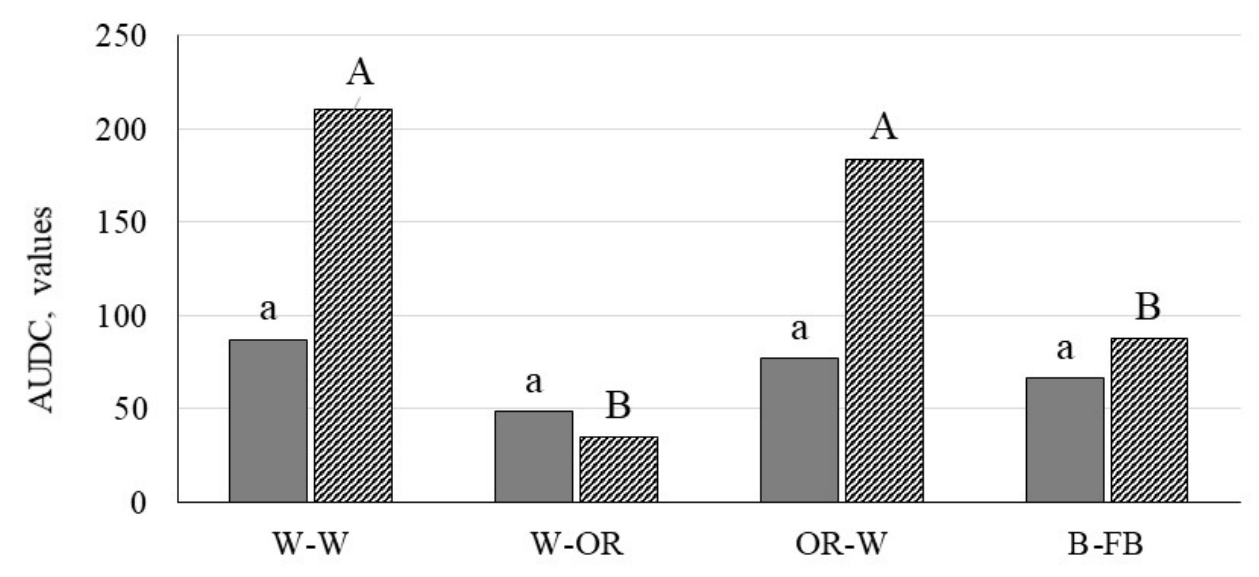

$\square$ Ploughed Without ploughing

Figure 4. Development of tan spot depending on crop rotation (pre-pre-crop and pre-crop) and soil tillage method: $\mathrm{W}$ - wheat; OR - oilseed rape; B - barley; FB - faba bean (significantly different means are labelled with different letters: A, B - significant difference for AUDPC of unploughed fields; $\mathrm{a}, \mathrm{b}-$ for ploughed fields).

compared to continuous wheat sowings (Figure 3).

The impact of crop rotation was influenced by the method of soil tillage in relation to $\tan \operatorname{spot}(\mathrm{p}=0.002)$. Wheat as pre-crop significantly increased the development of tan spot in un-ploughed fields, regardless of pre-pre-crop. Ploughing mitigate effect of previous crops and differences in tan spot level were insignificant (Figure 4).

Rapid development of Septoria leaf blotch started only after heading. The level of this disease was not influenced by crop rotation $(\mathrm{p}=0.506)$ or by combination between soil tillage and pre-pre-crop $(\mathrm{p}=0.698)$.

\section{Discussion}

Control of wheat leaf diseases is one of the most important problems of grain production in many countries, where wheat is important agricultural crop, accordingly the research of factors that promote development of these diseases is meaningful. Tan spot and Septoria leaf blotch are the most important in Nordic-Baltic region, other diseases - mildew (caused by Blumeria graminis) and rusts (caused by Puccinia striiformis and $P$. recondita) are harmful only occasionally. However, in Latvia, similar to Lithuania tan spot dominates almost each year, but Septoria leaf blotch is considered the most devastating disease of wheat, regardless of the cultivar, year and management in the rest of other countries in this region, also elsewhere in Europe (Bankina et al., 2018; Hýsek, Vavera, \& Rủžek, 2019; Jalli et al., 2020).

Similar to our previous studies, tan spot strongly 
dominated in all years of investigation. The level of this disease was similar in three out of four years, regardless of different meteorological conditions (Table 1). The highest level of tan spot was observed in 2019, when the period of wheat development (GS 32-75) was dry, but warmer than usual. Obtained results proved, that the development of tan spot little depends on meteorological conditions, but agronomic practice determines severity of this disease.

Septoria leaf blotch was almost not observed in extremely dry 2018, but the highest level was noticed in 2019 and 2020 although meteorological conditions (amount of precipitation and average temperature) were different in these years. However, we have considered, that the level of Septoria leaf blotch correlated with the number of rainy days during the growth stage (GS) 32-55; during this time 17 and 19 rainy days were registered accordingly (Table 1).

Conservation soil tillage becomes more and more popular around the world, and it is considered as a possibility to save biological diversity and soil fertility. On the other hand, ploughing and crop rotation have been recommended to diminish application of fungicides and herbicides (Andert et al., 2016). Our results support findings of several authors, which highlighted that reduced tillage promotes the development of tan spot. The level of tan spot was significantly higher in unploughed fields. In this period of studies, we got the same result as in the previous research during 20102017 (Bankina et al., 2015; Bankina et al., 2018) ploughing did not decrease the level of Septoria leaf blotch. Consequently, infected plant debris is not an important source of infection in our conditions.

Importance of crop rotation as the main tool to decrease the level of tan spot was revealed in several investigations, including our previous studies. In this period, we evaluated the impact or pre-crop and pre-pre-crop combination. It was proved that one-year break significantly reduced the level of tan spot, regardless of previous crop. This statement is not in agreement with previous findings (Fernandez et al., 2016b). In our previous studies, the level of Septoria leaf blotch was not affected by pre-crop or combination of pre-crops. These findings agree with previous studies that the development of Septoria leaf blotch depends more on meteorological conditions compared with agronomic practice (Cotuna, Paraschivu, \& Olaru, 2018).

Pseudothecia in the residues of wheat straw is the main infection source of Pyrenophora tritici-repentis; therefore, the rate of pseudothecia decomposition is very important, it could be influenced not only by agronomic practise, but also by soil microbiological activity and relationships between different organisms. It was found that soil dehydrogenase activity is higher in the fields with reduced soil treatment, which could be prerequisite for faster decaying of plant residues and diversity of microbiological community (Dubova, Ruža, \& Alsiņa, 2016; Majchrzak et al., 2016). In general, reduced soil tillage increases richness of fungal communities, but this effect depends on crop rotation, particular site and meteorological conditions of year (Sharma-Poudyal et al., 2017). Soil tillage systems did not significantly influence soil fungal communities in experiments conducted at the Washington State University Dryland Research Station (Schlatter et al., 2017).

However, our investigations proved that all these considerations do not reflect real situations. The level of tan spot was essentially lower in all ploughed fields, ploughing completely mitigated the impact of pre-crops, even continuous wheat sowings. On the contrary, crop rotation becomes extremely important in case of reduced soil tillage. Similar results were obtained a few years ago (Bankina et al., 2018; Bankina et al., 2015), but importance of ploughing becomes more clearly visible during a longer period of time.

Agronomic practice did not influence the development of Septoria leaf blotch in our trials, which is in contradiction to other studies. Reduced soil tillage and monocropping of wheat essentially increased the development of Septoria leaf blotch under Mediterranean conditions (Calzarano et al., 2018). It is difficult to explain our results; possibly, the level of Septoria leaf blotch was too low to make any conclusions. Early development of Septoria leaf blotch was not observed in our study, the progress of the disease started only after heading. Similar results were obtained in other trials in Latvia - severity of leaf blotches was low till the beginning of heading (Bankina et al., 2014). Residues of plants were not considered as the main source of infection with Zymoseptoria tritici, rather this was living wheat. Possibly, the results were influenced by the relationships between Pyrenophora tritici-repentis and Zymoseptoria tritici, which has not been sufficiently studied yet.

\section{Conclusions}

Tan spot, caused by Pyrenophora tritici-repentis was the dominated disease over a long period regardless of meteorological conditions. The pre-crop (oilseed rape or faba beans) significantly decreased the level of tan spot independently of pre-pre-crops. Reduced soil tillage essentially increased the development of tan spot, and ploughing mitigates the impact of crop rotation. The impact of agronomic practice is not clear regarding the development of Septoria leaf blotch. Further research is required to clarify the relationships between these diseases and the traits of Septoria leaf blotch development. 


\section{References}

Andert, S., Bürger, J., Stein, S., \& Gerowitt, B. (2016). The influence of crop sequence on fungicide and herbicide use intensities in North German arable farming. European Journal of Agronomy, 77, 81-89. DOI:10.1016/ j.eja.2016.04.003.

Bankina, B., Bimšteine, G., Arhipova, I., Kaņeps, J., \& Stanka, T. (2018). Importance of agronomic practice on the control of wheat leaf diseases. Agriculture, 8(4), 56. DOI:10.3390/ agriculture 8040056.

Bankina, B., Gaile, Z., Balodis, O., Bimšteine, G., Katamadze, M., Kreita, D., . . . Priekule, I. (2014). Harmful winter wheat diseases and possibilities for their integrated control in Latvia. Acta Agriculturae Scandinavica, Section B-Soil \& Plant Science, 64(7), 615-622. DOI: 10.1080/ 09064710.2014 .949296$.

Bankina, B., Ruža, A., Paura, L., \& Priekule, I. (2015). The effects of soil tillage and crop rotation on the development of winter wheat leaf diseases. Zemdirbyste-Agriculture, 102(1). DOI: 10.13080/z-a.2015.102.008.

Biberdzic, M., Barac, S., Lalevic, D., Djikic, A., Prodanovic, D., \& Rajicic, V. (2020). Influence of soil tillage system on soil compaction and winter wheat yield. Chilean journal of agricultural research, 80(1), 80-89. DOI: 10.4067/ S0718-58392020000100080.

Calzarano, F., Stagnari, F., D’Egidio, S., Pagnani, G., Galieni, A., Di Marco, S., . . Pisante, M. (2018). Durum wheat quality, yield and sanitary status under conservation agriculture. Agriculture, 8(9), 140. DOI: 10.3390/agriculture8090140.

Conyers, M., van der Rijt, V., Oates, A., Poile, G., Kirkegaard, J., \& Kirkby, C. (2019). The strategic use of minimum tillage within conservation agriculture in southern New South Wales, Australia. Soil and Tillage Research, 193, 17-26. DOI: 10.1016/j.still.2019.05.021.

Cotuna, O., Paraschivu, M., \& Olaru, L. (2018). Influence of crop management on the impact of Zymoseptoria tritici in winter wheat in the context of climate change: an overview. Research Journal of Agricultural Science, 50(3), 69-76.

Cárcer, P. S. de, Sinaj, S., Santonja, M., Fossati, D., \& Jeangros, B. (2019). Long-term effects of crop succession, soil tillage and climate on wheat yield and soil properties. Soil and Tillage Research, 190, 209-219. DOI: 10.1016/j.still.2019.01.012

Dubova, L., Ruža, A., \& Alsiņa, I. (2016). Soil microbiological activity depending on tillage system and crop rotation. Agronomy Research, 14(4), 1274-1284.

Fernandez, M. R., Stevenson, C. F., Hodge, K.,
Dokken-Bouchard, F., Pearse, P. G., Waelchli, F., . . Peluola, C. (2016a). Assessing effects of climatic change, region and agronomic practices on leaf spotting of bread and durum wheat in the western Canadian Prairies, from 2001 to 2012. Agronomy Journal, 108(3), 1180-1195. DOI: 10.2134/agronj2015.0451.

Fernandez, M., Wang, H., Cutforth, H., \& Lemke, R. (2016b). Climatic and agronomic effects on leaf spots of spring wheat in the western Canadian Prairies. Canadian Journal of Plant Science, 96(5), 895-907.DOI: 10.1139/cjps-2015-0266.

Fernandez, M. R., Zentner, R. P., Schellenberg, M. P., Aladenola, O., Leeson, J. Y., Luce, M. S., . . . Cutforth, H. (2019). Soil fertility and quality response to reduced tillage and diversified cropping under organic management. Agronomy Journal, 111(2), 781-792. DOI: 10.2134/ agronj2018.01.0028.

Hýsek, J., Vavera, R., \& Růžek, P. (2019). Cultivation Intensity in Combination with Other Ecological Factors as Limiting Ones for the Abundance of Phytopathogenic Fungi on Wheat. Microbial ecology, 78(3), 565-574. DOI: 10.1007/s00248019-01337-3.

Jalli, M., Kaseva, J., Andersson, B., Ficke, A., Nistrup-Jørgensen, L., Ronis, A., . . . Djurle, A. (2020). Yield increases due to fungicide control of leaf blotch diseases in wheat and barley as a basis for IPM decision-making in the NordicBaltic region. European Journal of Plant Pathology, 1-19. DOI: 10.1007/s10658-020-02075-w.

Kadziene, G., Suproniene, S., Auskalniene, O., Pranaitiene, S., Svegzda, P., Versuliene, A., . . . Feiza, V. (2020). Tillage and cover crop influence on weed pressure and Fusarium infection in spring cereals. Crop Protection, 127, 104966. DOI: 10.1016/j.cropro.2019.104966.

Majchrzak, L., Sawinska, Z., Natywa, M., Skrzypczak, G., \& Głowicka-Wołoszyn, R. (2016). Impact of Different Tillage Systems on Soil Dehydro genase Activity and Spring Wheat Infection. $J$. Agr. Sci. Tech., 18, 1871-1881.

Matušinsky, P., Váňová, M., Tvarůžek, L., Polišenská, I., Janeček, M., \& Smutný, V. (2016). Soil management technologies and mycotoxin contamination of wheat and barley grain. Cereal Research Communications, 44(2), 320-329. DOI: 10.1556/0806.44.2016.021.

Mazzilli, S. R., Ernst, O. R., de Mello, V. P., \& Pérez, C. A. (2016). Yield losses on wheat crops associated to the previous winter crop: Impact of agronomic practices based on on-farm analysis. European Journal of Agronomy, 75, 99-104. DOI: 10.1016/ j.eja.2016.01.007. 
Pagnani, G., Galieni, A., D’Egidio, S., Visioli, G., Stagnari, F., \& Pisante, M. (2019). Effect of soil tillage and crop sequence on grain yield and quality of durum wheat in Mediterranean areas. Agronomy, 9(9), 488. DOI: 10.3390/agronomy 9090488.

Schlatter, D. C., Schillinger, W. F., Bary, A. I., Sharratt, B., \& Paulitz, T. C. (2017). Biosolids and conservation tillage: Impacts on soil fungal communities in dryland wheat-fallow cropping systems. Soil Biology and Biochemistry, 115, 556-567. DOI: 10.1016/j.soilbio.2017.09.021.

Sharma-Poudyal, D., Schlatter, D., Yin, C., Hulbert, S., \& Paulitz, T. (2017). Long-term no-till: a major driver of fungal communities in dryland wheat cropping systems. PloS one, 12(9), e0184611.

Vega, D., Gally, M. E., Romero, A. M., \& Poggio, S. L. (2019). Functional groups of plant pathogens in agroecosystems: a review. European Journal of Plant Pathology, 153(3), 695-713. DOI: 10.1007/s10658-018-01616-8.

Willocquet, L., Meza, W. R., Dumont, B., Klocke, B., Feike, T., Kersebaum, K. C., . . . Savary, S. (2020). An outlook on wheat health in Europe from a network of field experiments. Crop Protection, 139, 105335. DOI:10.1016/j.cropro. 2020.105335 .

\section{Acknowledgement}

The research was supported by the grant from the Latvia Ministry of Agriculture "Influence of minimal soil tillage on its fertility maintenance, development and distribution of pests as well as crops' yield and quality in resowings" and project "Features of tan spot of winter wheat caused by Pyrenophora tritici-repentis development and control possibilities in Latvia and Belarus". 